\section{Lytvyn V., Uhryn D., Iliiyuk $\mathbf{0 .}$ Klichuk 0.}

\title{
DEVELOPMENT OF A METHOD FOR CALCULATING THE SAFE POSITION OF MILITARY UNITS BY USING ARTIFICIAL NEURAL NETWORKS BASED ON SWARM ALGORITHMS
}

Запропоновано метод пошуку безпечної позиції військових одинищь під час ведення бойових дій шляхом використання нейронних мереж та алгоритму жаб. Розроблено математичну модель методу пошуку безпечної позицї військових одиниць шляхом використання штучних нейронних мереж. Побудовано гібридний алгоритм пошуку безпечної позииії на основі алгоритму ройового інтелекту. Визначені області потенщійного застосування методу.

Ключові слова: нейронні мережі, безпечна позиція, прогнозування рішень, покрив кластерів.

\section{Introduction}

A well-known fact is that with the development of technologies, the needs of mankind are increasing. In the same way, in the military sphere, needs are growing. Today, swarm algorithms used in developing various methods and mathematical models of military problems are effective [1-3].

Neural networks are widely used in the modern world through their adaptability to the tasks of a different plan. Their feature is that neural networks are a network of artificial cells, which in turn have memory [3-7]. This property can be used in different directions, including in the construction and solution of transport-type problems.

An important step in designing the search process for the safe position of the fire potential is the calculation of optimization of the technical and economic characteristics of parameters using the swarm algorithms.

In modern times, most combat operations are carried out remotely, so it is timely to identify the enemy's position with its own shots or other aggressive actions.

\section{The object of research and its technological audit}

The object of this research is the process of searching for the safe path of military units from the initial position to the final one. An important step in the formation of a process of this type was to determine the information containing each cell of memory, which in turn is a group of military units [8-12]. The memory cell is a cluster, that is, it is the area of the site, has a number of handler functions. Functions handlers are elements of the process of forming the final result, since each cell interacts with each other. Let's conclude that the functions, processing the information in the cluster, produce the final result. The logical scheme of information processing in clusters is shown in Fig. 1.

Thus, a network is created that has the ability to output the result at any stage of information processing, since its interaction is autonomous.

One of the most problematic areas is the definition of the type of warfare that shoots through a certain area of the site and enters into the development of the cluster the technical characteristics of this shell.

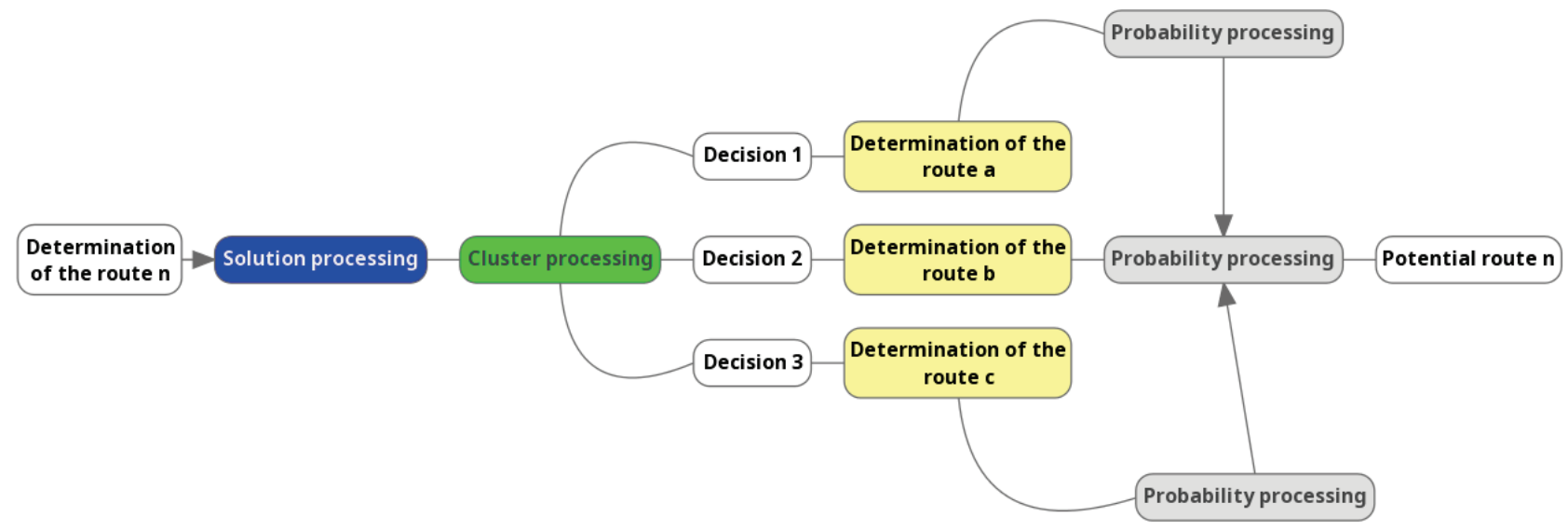

Fig. 1. Logical scheme of information processing in a cluster 
In this paper, a potential solution to the transport problem in military specialization, namely, the conduct of military operations in a certain territory is described. Tasks of this type require careful study of all subjects and objects of research, as well as accounting and calculation of all possible errors.

\section{The aim and objectives of research}

The aim of research is development of a method for searching a safe route for military units in hazardous areas by applying a neural network and using the algorithm of frogs.

To achieve this aim it is necessary to:

1. Construct a multi-objective military-type problem.

2. Identify potential participants in the search for a safe position in hazardous areas.

3. Analyze the method developed using statistical data of obtained layers of neural networks based on the results obtained by the method of frogs.

\section{Research of existing solutions of the problem}

In most cases, methods of developing neural networks minimize the presence of error solutions to obtain an accurate result [1-3]. For the majority of tasks, this approach is important, but when carrying out a task that contains the foundations of probabilities, the proposed approach is inadequate.

To solve transport-type problems, the classical approach is often used, namely the creation of a mathematical model by constructing a multicriteria problem [4-7]. Using modern swarm algorithms in combination with a mathematical model, it is possible to obtain much better results.

A common solution of problems of this type, namely military direction [8-10], uses the classical approach of constructing a mathematical model. This approach shows high results in the case of a solution at a certain point in time [11-13], and with the dynamics of changes in the characteristics of the problem, the efficiency is significantly reduced. Therefore, a promising direction in the field of military activities is the use of algorithms that will make decision adaptive changes.

In most cases, much attention is paid to the study of shells, their characteristics and properties. This is due to the modernization and application of modern technologies in military specialization. In order to determine the properties of a shell, it is necessary to build a mathematical model based on its characteristics. This approach will not cover a broad aspect, namely the general modeling process (mathematical, visual). An important aspect in solving problems of this type is the creation of a dynamic model, by means of which it is possible to determine the characteristics and properties of the shell at any given time. Therefore, accounting for errors in the calculations is an integral process.

Also, neural networks and methods of their training are popular today. To solve problems where it is required to determine at an exact moment in time, what characteristics and properties were at the object, use the method of training the neural network by using a genetic algorithm. This approach allows to obtain a stable solution, but with dynamic changes the result will change only in the next solution. This is because using the genetic algorithm, it is necessary to specify the initial solution (parents), only after processing the primary solution, it is possible to obtain the following. That is, if at a certain point in time, when the characteristics and properties of the object have not yet been calculated, changes can't be made.

\section{Methods of research}

This study focuses on the construction of an algorithm and the interaction of elements in the search for a safe path. In order to fulfill the set aims, it is necessary to use the method of reverse common error.

The method of reverse common error in this case is a multilayered coverage of the selected area with a superimposed grid. The grid $\vec{P}$ is specified by a vector of parameters $\vec{W}$ of weight coefficients and cover levels $\vec{M}$.

$$
\vec{P}=\frac{(\vec{W})}{(\vec{M})} .
$$

When processing the cover cluster $M$ at each iteration, i. e., the interaction of the mystery information is corrected in the direction of the antigragient $E$ :

$$
\wedge \vec{P}=-\varepsilon \forall E(\vec{P}) .
$$

The idea of the method is to present $E$ in the form of a complex function and consistently calculate the possible errors and coefficients of the parameters of the section $i$ and $j$ :

$$
\wedge W_{i j}=-\varepsilon\left(\frac{E(W, M)}{\omega}\right) .
$$

Let's formulate an expression for the general function $E / W_{i j}$, where $y$ is a predictable cover of the site:

$$
\frac{E}{W_{i j}}=\frac{E}{y_{i}} \frac{y_{i}}{S_{j}} \frac{S_{j}}{W_{i}}
$$

For subsequent layers, the formula will look like this:

$$
\begin{aligned}
& \frac{E}{y_{i j}}=\sum_{M} \frac{E}{\delta x_{j k(l+1)}}=\sum_{M} \frac{E}{\delta y_{k(l+1)}} \cdot \frac{d y_{k(l+1)}}{d S_{k(l+1)}} \times \\
& \times \frac{d S_{k(l+1)}}{d x_{j k(l+1)}}=\sum_{M} \frac{E}{\delta y_{k(l+1)}} \cdot \frac{d y_{k(l+1)}}{d S_{k(l+1)}} \cdot w_{j k(l+1)} .
\end{aligned}
$$

The sum $M$ is the sum over the interaction of the layers of the cover from the lower to the upper and vice versa.

Thus, it is possible to construct an inverse interaction of error propagation along the neural network applied to the transport problem.

A method that simulates the proliferation of military units, based on the behavior of frogs, jumping from place to place in search of food. In this study, the method of transition from one population (the accumulation of military units (MU)) to another is implemented. The population is represented by a multitude $P$ of military units divided into $M$ subsets of military units possessing a parameter of the MU number is the same and are called a MU group. 
Within each group, a local search occurs. At the same time within the group there is a better $E_{\text {best }}$ solution and worse $E_{\text {worrst }}$. Then the situation of the MU group (frogs) worse (with the worst value of the objective function) changes according to the following rule:

$$
E_{\text {woorst }}^{\text {new }}=x_{\text {worst }}+\mid \text { Crand }\left[x_{\text {best }}-x_{\text {woorst }}\right] \text {, }
$$

where rand is a random vector which elements are uniformly distributed on an interval $[0 ; 1] l, C$ is a coefficient. If the obtained solution $E_{\text {woorst }}^{\text {new }}$ is better than $E_{\text {zoorst }}$, then it replaces it. Otherwise, there is a new position of the MU according to formula (7), where instead of the best solution $E_{\text {best }}$ within the group, the best solution among all MU deployments in the algorithm population $E_{g b}$ is used. If the newly obtained solution satisfies the conditions of the problem, then the worst solution is replaced by the best solution from the obtained populations of the MU location.

After the local division of the population has been completed, MU is implemented again so that it becomes possible to obtain an alternating solution, which is shown in Fig. 2. In this case, all solutions are ordered by the value of the objective function coefficient.

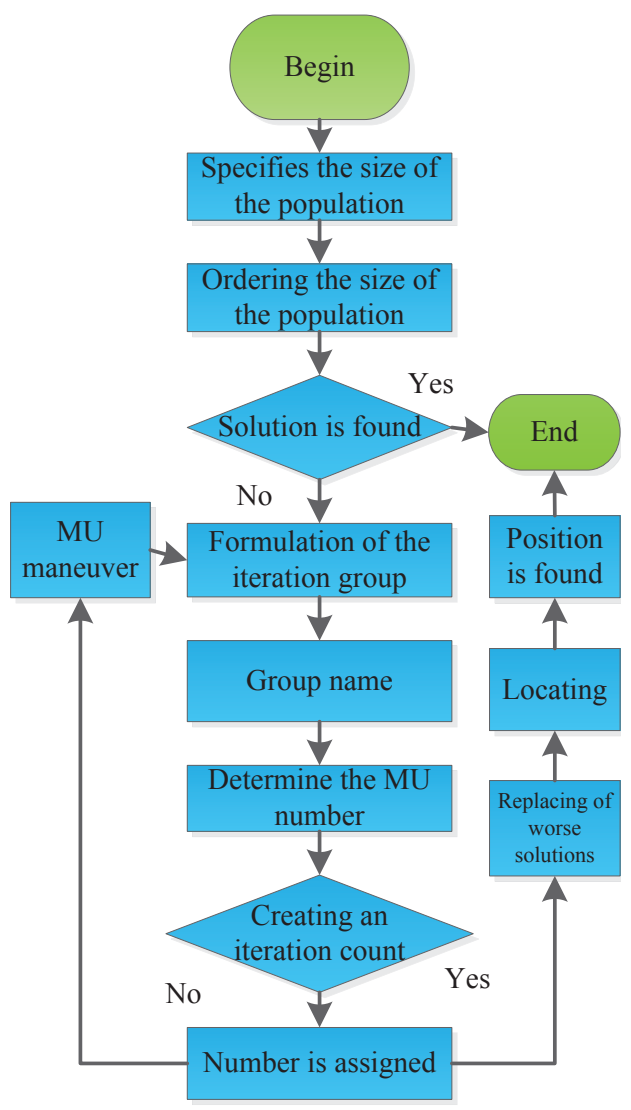

Fig. 2. Algorithm for the distribution of military units

The solution search algorithm is carried out in the following steps:

Step 1. Set the population size $P$, the number of MU groups $M$ and the parameter $C$, and the maximum number of iterations ITER.

Step 2. Generating the MU initial population on the set $D$ using a uniform distribution. Calculation of the value of the objective function for each MUs.
Step 3. Arrange the elements of the population in accordance with the coefficient of the objective function.

Step 4. The formulation of the best solution $M$ from the population and its use in the next population. The result is MU $M$ group that contains the same number of MUs.

Step 5. Within each group, conduct a specified number of iterations of the local search for MU maneuver (jumps of frogs).

Step 6. The name of the MU groups in the created groups, that is, giving them value $N U M$.

Step 6.1. Set $N U M=1$ (group number).

Step 6.2. Set the local search iteration count $i t=1$.

Step 6.3. Within the group with the assigned number, find the best solution and worse.

Step 7. Replacing the worst solutions in the MU population assigned to the MU group numbers.

Step 8. Finding a new position of MU groups:

$$
E_{\text {woorst }}^{\text {new }}=x_{\text {worst }}+\mid \text { Crand }\left[x_{\text {best }}-x_{\text {worst }}\right] \text {. }
$$

Step 9. Otherwise, the value of the objective function is replaced, if $f\left(x_{\text {woors }}^{\text {ner }}\right) \triangleright f\left(x_{\text {woort }}\right)$, then replace the solution $E_{\text {worst }}$ in $E_{\text {weorst }}^{\text {new }}$. Otherwise, generate solutions $E_{\text {woorst }}^{\text {new }}$ randomly on a set $D$ using a uniform distribution.

Step 10. If $i t=I T$, then the local search in the group is completed. After checking the numbering of groups and fixing the location to local points.

The algorithm of the step-by-step scheme for calculating the constraints of the target area is shown in Fig. 3.

A necessary condition is also the construction of a multicriteria problem. With regard to the error of the trajectory of the enemy's shell, a safe position is determined and the military units regroup. Therefore, in the error of the shell's flight, let's consider the time of its flight and the defeat of a certain area.

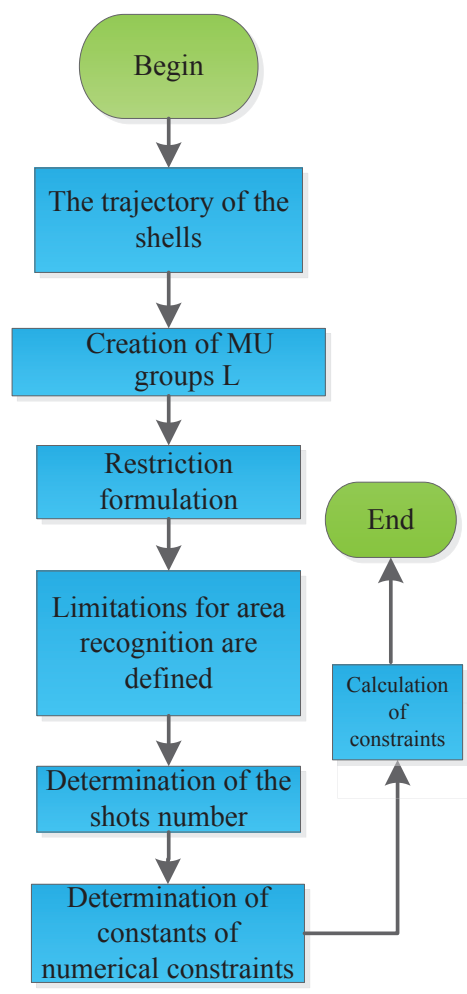

Fig. 3. Mathematical model of the multicriteria problem of calculation of numerical restrictions of a safe position 
So, with the known error value, it is possible to construct the following mathematical model of the algorithm shown in Fig. 3:

1. The specified trajectory of flights of shells $X$.

2. Given groups of military units $L$ for each of which a given reference trajectory is $X_{\text {anom }}^{L}$.

3. Limitations on the accuracy of recognition of the area for its safety are given: $e_{1} \prec$ const $_{1}$ and $e_{2} \prec$ const $_{2}$, where $e_{1}-$ the number of shots of the first shell; $e_{2}$ - the number of shots of the second shell; const $_{1}$ and const $_{2}$ are the specified numerical limitations.

\section{Research results}

Applying the proposed method on the example of the transport task in military specialization, one can obtain the reciprocal interaction on each cover of the territory by a neural network. That is, it is possible to see the result of the interaction of each error, object, subject against each other under different situational data sets.

Such data can be information of various kinds:

1. Calculations of the search for a safe position in various conditions (field, combat, land movement, sea movement and others).

2. Calculations of errors and their interaction.

3. The trajectory of the shell's flight under various conditions.

4. Search for local points, areas suitable for conducting fire or reconfiguring troops.

Let's apply the frog algorithm for the maneuver of military units and impose a neural network on the map of the territory of the Donetsk region (Ukraine), as shown in Fig. 4.

Use of a neural network will provide sustainable values for all participants in the process, such as:

1. Military units (MU) 1, 2, 3, carrying out a maneuver in Avdiivka and consolidating into one group of two participants.

2. MU 1, 2 (red color) - this is the forces of the enemy, which are at a distance of $10-12 \mathrm{~km}$ from military groups $1,2,3$.

The next step, shown in Fig. 5, will regroup military units according to a given algorithm.

After determining the participants in the process and the kilometer zone of damage, it is possible to get the safe position shown in Fig. 6 .

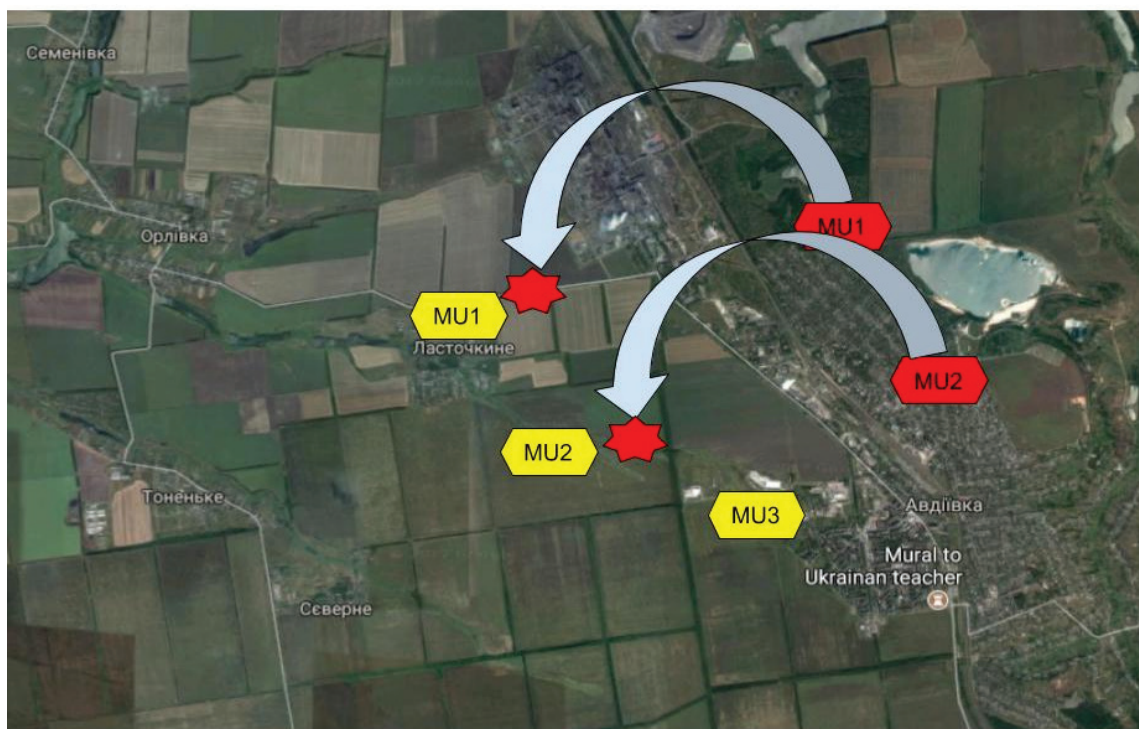

Fig. 4. Map of Donetsk region (Ukraine) during military operations

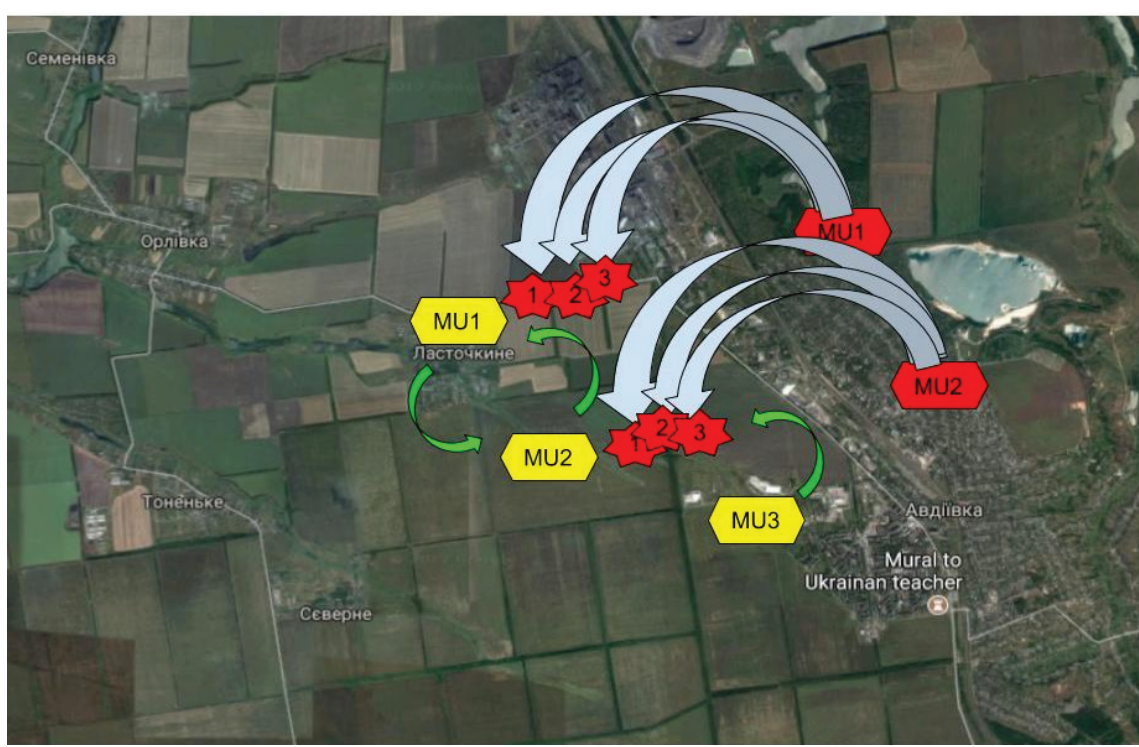

Fig. 5. The maneuver of military units

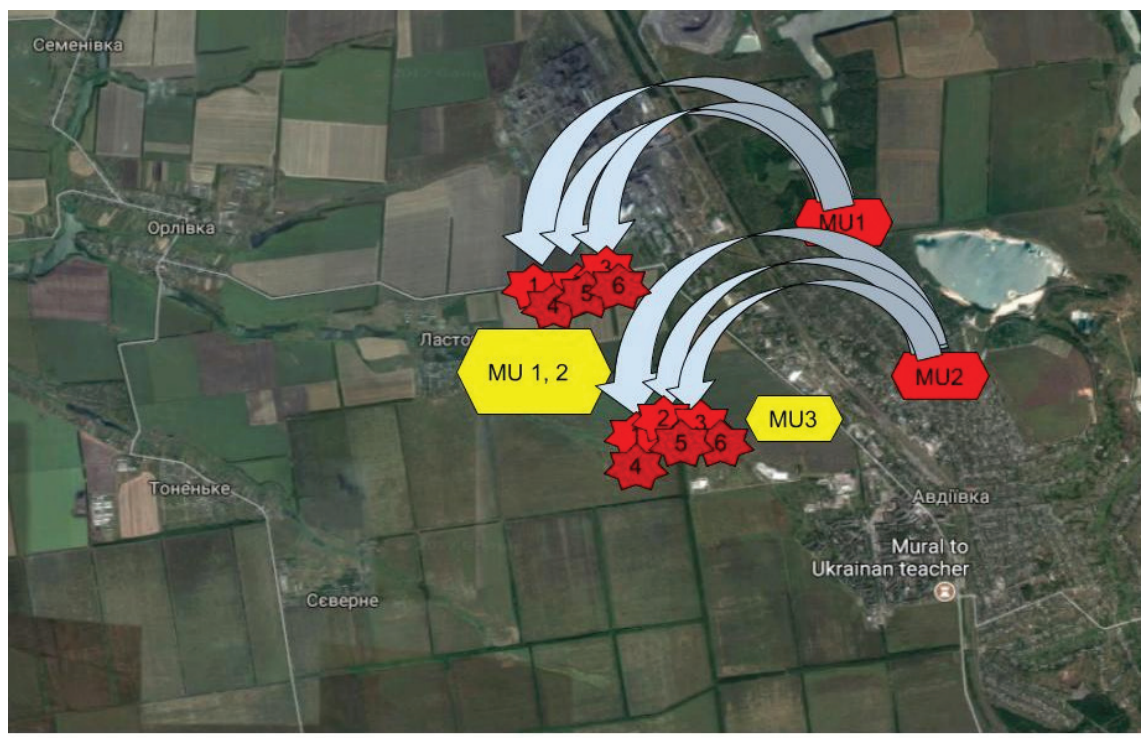

Fig. 6. Getting the result of maneuver 
Certain errors regarding the first shot are determined guided by fire potential. Numbers of areas of potential damage are certain stars 4, 5, 6 of dark red color. These results were obtained on the basis of the calculation of all the errors with respect to the trajectory of the shell, the flight time and the affected zone. To ensure the security of the military forces, let's obtain the following unification of military units in the group and the movement of the MU3 to Avdiivka.

The statistical data of the obtained results are shown in Table 1 according to the following parameters:

1. MU group.

2. Military potential (values from 1-50).

3. Damage area in kilometers.

4. Shot accuracy (values from 1-5).

5. Shot number.

Table 1

Tests of the first round of shots

\begin{tabular}{|c|c|c|c|c|c|}
\hline$X$ & \multicolumn{5}{|c|}{ Test 1 } \\
\hline$L_{\text {anom }}$ & 1 & 2 & 3 & 1 & 2 \\
\hline$L_{1}$ & 20 & 22 & 25 & 27 & 40 \\
\hline$L_{k m}^{\text {anom }}$ & 10 & 11 & 10 & 9 & 12 \\
\hline Const $_{1}$ & 3 & 2 & 5 & 1 & 2 \\
\hline Const $_{2}$ & 5 & 3 & 2 & 2 & 0 \\
\hline$e_{1}$ & 2 & 3 & 2 & 2 & 2 \\
\hline
\end{tabular}

There are changes after the MU maneuver listed in Table 2.

Table 2

Tests of the second round of shots

\begin{tabular}{|c|c|c|c|c|c|}
\hline$X$ & \multicolumn{5}{|c|}{ Test 1} \\
\hline$L_{\text {anom }}$ & 1 & 2 & 3 & 1 & 2 \\
\hline$L_{1}$ & \multicolumn{2}{|c|}{42} & 28 & 12 & 20 \\
\hline$L_{k m}^{\text {anom }}$ & \multicolumn{2}{|c|}{9} & 5 & 0 & 0 \\
\hline Const $_{1}$ & 3 & 2 & 5 & 0 & 0 \\
\hline Const $_{2}$ & 5 & 3 & 2 & 0 & 0 \\
\hline$e_{1}$ & 2 & 3 & 2 & $2+$ & $2+$ \\
\hline
\end{tabular}

As it is possible to see, the military potential of groups 1 and 2 increased due to their unification. Kilometer zone of defeat decreased, so the military potential of Group 3 was grown. The military potential of enemy 1 and 2 has been halved, since the shot of the second stage has not undergone any results and it became necessary to perform the gunshots again blindly, so the enemy's costs doubled. And groups 1, 2, 3 carried out reconfiguration of military forces and received great firepower. A comparison of the characteristics of the search for a safe position by classical and hybrid methods (Table 3 ) are shown in Fig. 7.

At a time when the proposed hybrid method makes it possible to obtain the results (Table 4), are shown in Fig. 8, it is possible to conclude that such method is much more effective than the classical approach of constructing a mathematical model. Using the classical approach, one can only calculate the approximate position of the enemy, and if any statistical data change, the result loses its accuracy.
Table 3

Comparison of method parameters

\begin{tabular}{|l|c|c|}
\hline \multicolumn{1}{|c|}{ Methods } & $\begin{array}{c}\text { Classical } \\
\text { methad }\end{array}$ & $\begin{array}{c}\text { Hybrid } \\
\text { methods }\end{array}$ \\
\hline Military potential & 25 & 42 \\
\hline Number of MU groups & 1 & 2 \\
\hline Distance error, km & 0 & 2 \\
\hline Trajectory accuracy (0-5) & 2 & 5 \\
\hline Maneuver (0 - none, 1 - available) & 0 & 1 \\
\hline Number of counted shots & 1 & 2 \\
\hline Area coverage (0 - none, 1 - available) & 0 & 1 \\
\hline
\end{tabular}

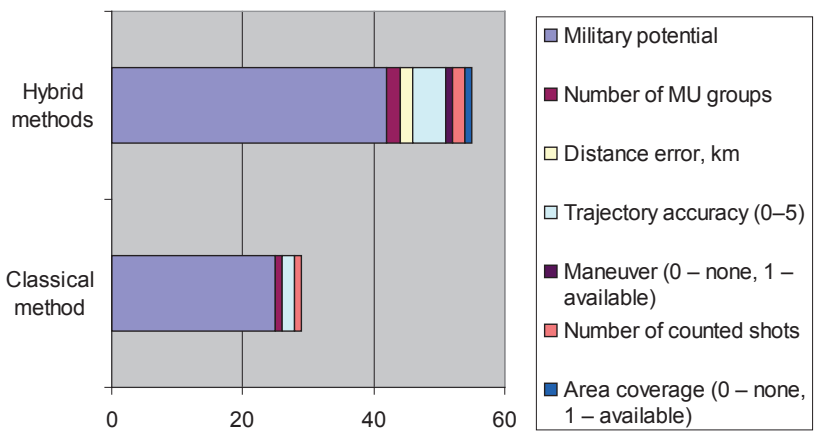

Fig. 7. Diagram of comparison of classical and hybrid methods

Table 4

Comparison of error calculation for methods

\begin{tabular}{|l|c|c|}
\hline \multicolumn{1}{|c|}{ Methods } & $\begin{array}{c}\text { Classical } \\
\text { method }\end{array}$ & $\begin{array}{c}\text { Hybrid } \\
\text { methods }\end{array}$ \\
\hline Distance error, km & $10 \%$ & $25 \%$ \\
\hline Shell trajectory error & $0 \%$ & $25 \%$ \\
\hline Accuracy of the damage area & $0 \%$ & $15 \%$ \\
\hline Shots error & $55 \%$ & $10 \%$ \\
\hline Time error between shots & $0 \%$ & $10 \%$ \\
\hline Flight time error & $35 \%$ & $10 \%$ \\
\hline Accuracy of the time spent on maneuver & $0 \%$ & $5 \%$ \\
\hline
\end{tabular}

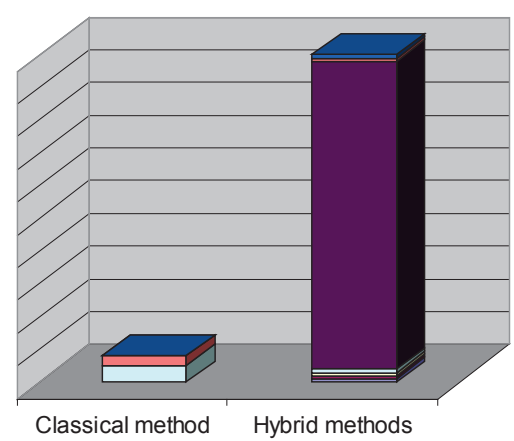

\begin{tabular}{|l|}
\hline Accuracy of the time \\
spent on maneuver \\
$\square$ Flight time error \\
$\square$ Time error between \\
shots \\
$\square$ Shots error \\
$\square$ Accuracy of the \\
damage area \\
Shell trajectory error \\
$\square$ Distance error, km
\end{tabular}

Fig. 8. Comparison diagram of the errors in the characteristics

Thanks to the use of neural networks, each shot is remembered and, accordingly, an error is calculated in the affected area. As a consequence, the result is a safe 
position, which should fire potential. Maneuver is carried out with the help of the algorithm of frogs in such way that the position has a fire potential under the given restrictions.

\section{SWOT analysis of research results}

Strengths. Among the strengths of this research is that when searching for a safe position in combat conditions, a hybrid method is used, which allows obtaining a more accurate result, due to the imposition of a neural network on the cover of the territory.

Weaknesses. The weak side of the research is that technical potential should be used to test the proposed method. Namely, to test the method on a military training ground with the necessary equipment and weapons.

Opportunities. Additional features that will ensure a more effective result, application and testing of the proposed method in Europe. To test the method of calculating a safe position on the fire potential at joint military exercises of Ukraine with partner countries. Such approach will make it possible to test the method for the effectiveness of its implementation.

Threats. Complexity with application of this method is due to the fact that it is possible to check efficiency only with the help of computer technologies.

Thus, SWOT analysis of the research results makes it possible to determine that when searching for a safe route during combat operations, it is necessary to use universal methods and technical equipment.

\section{Conclusions}

1. In constructing a multicriteria task and developing a mathematical model for the search for a safe position of military units in hazardous areas, a number of issues are resolved:

1) determination of the characteristics of participants in the process according to the data inherent only to them;

2) calculation of errors is carried out at the previous stage, that is, they are set in the construction of a multicriteria problem;

3) flexibility parameter of the algorithmization of this process is taken into account.

2. It is revealed that participants in the process of searching for a safe position in hazardous areas are:

1) shell that shoots through a section;

2) military units and groups;

3) clusters of plots.

3. Analysis of the developed method, which uses the statistical data of the obtained neural layers, shows the high efficiency of the classical approach. The effectiveness lies in the fact that, by calculating all the listed errors in two stages, the method allows to minimize the risk of being hit by hostile shells. In the classical approach, when searching for a safe position, only the general risk parameter is taken into account, while the hybrid method calculates the details of the possible risk of defeat and minimizes its value.

\section{References}

1. Wiener N. Extrapolation, Interpolation, and Smoothing of Stationary Time Series with Engineering Applications. Cambridge, MA: MIT Press, 1964. 176 p.
2. McCulloch W. S., Pitts W. A logical calculus of the ideas immanent in nervous activity // Bulletin of Mathematical Biology. 1990. Vol. 52, No. 1-2. P. 99-115. doi:10.1007/bf02459570

3. Hebb D. O. The Organization of Behavior: A Neuropsychological Theory. New York: Psychology Press, 2002. 335 p. doi:10.4324/9781410612403

4. Hopfield J. J. Neural networks and physical systems with emergent collective computational abilities // Proceedings of the National Academy of Sciences. 1982. Vol. 79, No. 8. P. 2554-2558. doi:10.1073/pnas.79.8.2554

5. Rumelhart D. E., Hinton G. E., Williams R. J. Learning Internal Representations by Error Propagation // Readings in Cognitive Science. 1988. P. 399-421. doi:10.1016/b978-1-48321446-7.50035-2

6. Shannon C. E. A Mathematical Theory of Communication // Mobile Computing and Communications Review. 2001. Vol. 5, No. I. P. 3-55.

7. Lippmann R. P. An introduction to computing with neural nets // ACM SIGARCH Computer Architecture News. 1988. Vol. 16, No. 1. P. 7-25. doi:10.1145/44571.44572

8. Sun-Yuan Kung, Taur J., Shang-Hung Lin. Synergistic modeling and applications of hierarchical fuzzy neural networks // Proceedings of the IEEE. 1999. Vol. 87, No. 9. P. 1550-1574. doi:10.1109/5.784235

9. Ackley D. H., Hinton G. E., Sejnowski T. J. A Learning Algorithm for Boltzmann Machines // Cognitive Science. 1985. Vol. 9, No. 1. P. 147-169. doi:10.1207/s15516709 $\operatorname{cog} 09017$

10. Loh W.-Y. Classification and regression trees // Wiley Interdisciplinary Reviews: Data Mining and Knowledge Discovery. 2011. Vol. 1, No. 1. P. 14-23. doi:10.1002/widm.8

11. Giles C. L., Maxwell T. Learning, invariance, and generalization in high-order neural networks // Applied Optics. 1987. Vol. 26, No. 23. P. 4972-4978. doi:10.1364/ao.26.004972

12. Farlow S. J. Self-Organizing Methods in Modeling: GMDH Type Algorithms (Statistics: A Series of Textbooks and Monographs). CRC Press, 1984. 368 p.

13. Hampshire J. B., Pearlmutter B. Equivalence Proofs for MultiLayer Perceptron Classifiers and the Bayesian Discriminant Function // Connectionist Models. 1991. P. 159-172. doi:10.1016/ b978-1-4832-1448-1.50023-8

\section{РАЗРАБОТКА МЕТОДА РАСЧЕТА БЕЗОПАСНОЙ ПОЗИЦИИ ВОЕННЫХ ЕДИНИЦ ПУТЕМ ИСПОЛЬЗОВАНИЯ ШТУЧНЫХ НЕЙРОННЫХ СЕТЕЙ НА ОСНОВЕ РОЕВЫХ АЛГОРИТМОВ}

Предложен метод поиска безопасного маршрута во время ведения боевых действий путем использования нейронных сетей и алгоритма лягушек. Разработана математическая модель метода поиска безопасной позиции военных единиц путем использования искусственных нейронных сетей. Построен гибридный алгоритм поиска безопасной позиции на основе алгоритма роевого интеллекта. Определены области потенциального использования метода.

Ключевые слова: нейронные сети, безопасная позиция, прогнозирования решений, покрытие кластеров.

Lytoyn Vasyl, Doctor of Technical Sciences, Professor, Department of Information Systems and Networks, Lviv Polytechnic National University, Ukraine, e-mail:yevhen.v.burov@lpnu.ua, ORCID: http:// orcid.org/0000-0002-9676-0180

Uhryn Dmytro, PhD, Associate Professor, Department of Information Systems, Chernivtsi Faculty of the National Technical University «Kharkiv Polytechnic Institute», Chernivtsi, Ukraine, e-mail: ugrund38@gmail.com,ORCID: http://orcid.org/0000-0003-4858-4511

Iliiyuk Olexiy, Department of Information Systems, Chernivtsi Faculty of the National Technical University «Kharkiv Polytechnic Institute», Chernivtsi, Ukraine, e-mail: olexiyilyukm@gmail.com, ORCID: https://orcid.org/0000-0002-0904-3045

Klichuk Oleg, PhD, Associate Professor, Department of Information Systems, Chernivtsi Faculty of the National Technical University «Kharkiv Polytechnic Institute», Chernivtsi, Ukraine, e-mail: Kolegr500@gmail.com, ORCID: https://orcid.org/0000-0002$7528-2968$ 